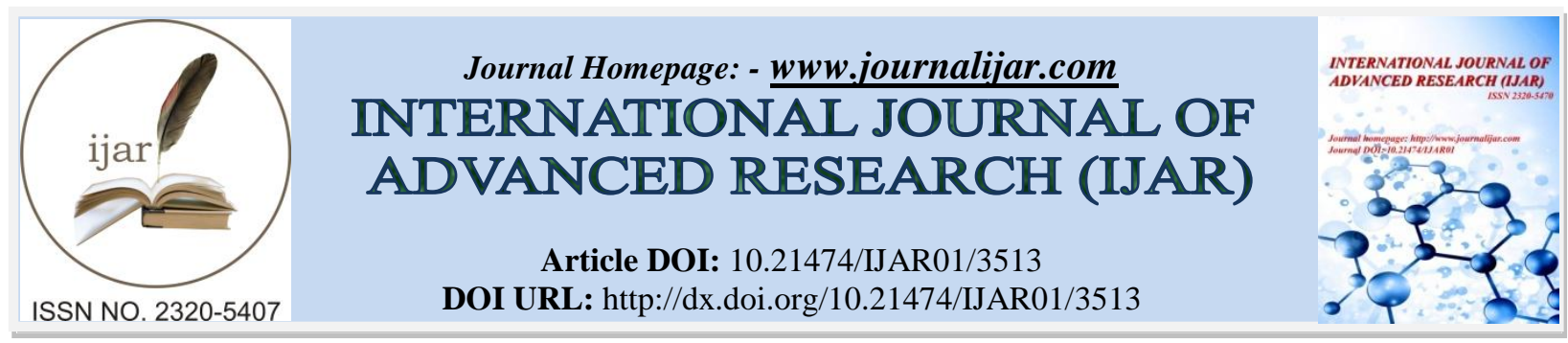

RESEARCH ARTICLE

\title{
QUANTITAIVE ESTIMATION OF HYDROQUINONE IN FOUR COSMETICS SAMPLES FROM LOCAL MARKET OF SANGAMNER TEHSIL, DISTRICT AHMEDNAGAR (M.S.), INDIA.
}

\author{
Bharati Kiran Tukaram*, Gujarathi Dipak Bansilal, Deshmukh Sanjay Sugandhrao, Sinare Sachin \\ Ramchandra and Gaikwad Rupali Kisan.
}

S. N. Arts, D. J. M. Commerce \& B.N.S Science College, Sangamner-422 605 India.

\section{Manuscript Info}

\section{Manuscript History}

Received: 01 January 2017

Final Accepted: 02 February 2017

Published: March 2017

Key words:-

Cosmetics, Hydroquinone, Oxidizing agent etc.

\begin{abstract}
Hydroquinone has been used for decades as a skin lightening agent. However the use of excessive concentration of hydroquinone in cosmetics poses skin problems hence was banned. Four cosmetics samples were sampled from the local market of Sangamner Tehsil, District Ahmednagar (M.S.), India. The labels on the packages did not indicate the presence of hydroquinone.

Hydroquinone can be quantitatively oxidised using mild solution of $\mathrm{H}_{2} \mathrm{O}_{2}$ in presence of catalytic amount of $\mathrm{Fe}^{+3}$ and the quinone is quantitatively estimated using Systronics Visible Double Beam Spectrophotometer Model-1203 at $363 \mathrm{~nm}$. The samples are found to contain $0.08641 \%$ to $0.11666 \% \mathrm{w} / \mathrm{w}$ hydroquinone and are said to be safe.

Copy Right, IJAR, 2017,. All rights reserved.
\end{abstract}

\section{Introduction:-}

Tyrosine is the precurser for the synthesis of melanin.Tyrosinase is the key and rate- limiting enzyme responsible for the conversion of tyrosine into melanin by melanocytes in human $\operatorname{skin}^{1,2}$.Many compounds that bind to the tyrosinase acitve site and inhibit melanin synthesis have been developed as agents to lighten skin color, including

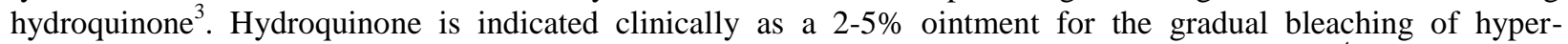
pigmented skin in conditions such as melasma, freckles and senile lentigines as well as chlousma ${ }^{4}$. Hydroquinone based products could be potential carcinogens as most of the benzene metabolites and derivatives are health hazards 5 . The U.S.Environmnetal Protection agency has not established a reference dose (RFD) for hydroquinone. However EPA has calculated a provisional RFD of $0.04 \mathrm{mg} / \mathrm{Kg} / \mathrm{d}$, hence there is no occurance of chronic, non cancer effects of this dose but as the amount and frequency of exposure exceeding the RFD increases, the probability of adverse health effects also increase ${ }^{6}$. So it has been recommended to ban in cosmetics. Several analytical methods for the determination of hydroquinone in skin preparations(cosmetics) are described, including High Performance Liquid Chromatography ${ }^{7,10}$ Capillary Electrochromatography ${ }^{11}$ and other Spectrophotometric techniques ${ }^{12-16}$.

The aim of the present study is to quantify the hydroquinone in some popular kinds of whitening creams in local market of Sanganmner tehsil, District Ahmednagar, (M.S.) India.

\section{Materials and Methods:-}

\section{Instrument:-}

The absorbances were measured using Systronics Visible Double Beam Spectrophotometer Model No.1203 with $1 \mathrm{~cm}$ rectangular quartz cells. 


\section{Chemicals and Reagents:-}

All the chemicals used were of analytical reagent grade. Distilled water was used for the preparation of all solution. $100 \mathrm{ppm}$ Standard solution of hydroquinone was prepared in water. $10 \mathrm{ppm}$ aq. $\mathrm{Fe}^{+3}$ in the form of $\mathrm{FeCl}_{3}$ were used as a catalyst and $0.6 \%$ solution of $\mathrm{H}_{2} \mathrm{O}_{2}$ was used as mild oxidising agent.

\section{Procedure for Spectrophotometric Determination of Hydroquinone:-}

2, 4, $6 \& 8 \mathrm{ml}$ of $100 \mathrm{ppm}$ hydroquinone were added into a series of labelled test tubes. To each tubes, 5 drops of $\mathrm{Fe}^{+3}$ and mild solution of $2 \mathrm{ml} \mathrm{H}_{2} \mathrm{O}_{2}$ were added. The contents were mixed well and heated in water bath at $100{ }^{0} \mathrm{C}$ for 20 minutes. The solutions were cooled at room temperature and diluted to $25 \mathrm{ml}$ using distilled water. The absorbances were measured within the stability period of $3 \mathrm{hrs}$ at $363 \mathrm{~nm}$ against reagent blank (Table 1). A calibration plot was obtained by plotting Absorbances versus ppm of Hydroquinone.

\section{Estimation of Hydroqunione in Cosmetics Creams:-}

$2 \mathrm{~g}$. of each sample was boiled with distilled water and contents were filtered through Whatmann No.42. This filtrate was diluted to $25 \mathrm{ml}$ with distilled water. Into a series of labelled test tubes; 2, 4, $6 \& 8 \mathrm{ml}$ of diluted sample solution was added. To each tube, 5 drops of $\mathrm{Fe}^{+3}$ and mild solution of $2 \mathrm{ml} \mathrm{H}_{2} \mathrm{O}_{2}$ were added. The contents were mixed well and heated in water bath at $100{ }^{\circ} \mathrm{C}$ for 20 minutes. After heating, the solutions were cooled at room temperature and diluted to $25 \mathrm{ml}$ using distilled water. The absorbances were measured within the stability period of $3 \mathrm{hrs}$ at $363 \mathrm{~nm}$ against reagent blank (Table 2).

\section{Results:-}

The hydroquinone content of each sample was deduced by extrapolation at corresponding Absorbance from Standard Curve (Table 3). The results of spectrophotometric analysis confirmed the presence of hydroquinone in four samples having varying levels. All the four samples contained less than $2 \%$ hydroquinone which is permicible limit given by WHO.

Table 1:- Absorbances for oxidation product at different concentration of HQ (Standard solution)

\begin{tabular}{|c|c|c|c|c|c|}
\hline Sr.No. & $\begin{array}{c}\mathrm{mL} \text { of } 100 \mathrm{ppm} \\
\mathrm{HQ}\end{array}$ & Drops of $\mathrm{Fe}^{+3}$ & $\mathrm{~mL}$ of $\mathrm{H}_{2} \mathrm{O}_{2}$ & Dilution (mL) & Absorbance \\
\hline 1 & 2 & 5 drops & 2 & 25 & 0.044 \\
\hline 2 & 4 & 5 drops & 2 & 25 & 0.166 \\
\hline 3 & 6 & 5 drops & 2 & 25 & 0.296 \\
\hline 4 & 8 & 5 drops & 2 & 25 & 0.311 \\
\hline
\end{tabular}

Table 2:- Absorbances for oxidation product at different concentration of HQ (Sample solutions)

\begin{tabular}{|c|c|c|c|c|}
\hline mL of sample & $\mathrm{S}_{1}$ & $\mathrm{~S}_{2}$ & $\mathrm{~S}_{3}$ & $\mathrm{~S}_{4}$ \\
\hline 2 & 0.115 & 0.075 & 0.066 & 0.077 \\
\hline 4 & 0.158 & 0.206 & 0.102 & 0.135 \\
\hline 6 & 0.162 & 0.249 & 0.175 & 0.327 \\
\hline 8 & 0.219 & 0.293 & 0.212 & 0.407 \\
\hline
\end{tabular}

Table 3:- HQ content of samples deduced from Standard Curve

\begin{tabular}{|c|c|c|}
\hline Sample & HQ in Working solution (ppm) & HQ in Sample (\% w/w) \\
\hline 1 & 72.72 & 0.0909 \\
\hline 2 & 93.33 & 0.1166 \\
\hline 3 & 69.13 & 0.0864 \\
\hline 4 & 86.15 & 0.1076 \\
\hline
\end{tabular}

\section{Conclusions:-}

1. In the present study, we developed a new method for quntitative estimation of hydroqunione in cosmetics samples. Mild solution of $\mathrm{H}_{2} \mathrm{O}_{2}$ was used for oxidation of hydroqunione to qunione in presence of catalytic $\mathrm{Fe}^{+3}$.

2. Although there is no adequate warning on product labels about the levels of hydroquinone present, this work revealed that the four collected samples of beauty creams from the study area contain $0.08641 \%$ to $0.1166 \%$ $\mathrm{w} / \mathrm{w}$ of hydroquinone and hence are said to be safe. 


\section{Acknowledgment:-}

We are thankful to Principal Dr K.K.Deshmukh for providing the facilities and motivation.

\section{References:-}

1. T.S.Chang “An Updated Review of Tyrosinase Inhibitors", International Journal of Molecular Sciences, 10(6), 2009, pp.2440-2475.

2. M. Mastore, L.Kohler and A.J.Nappi, "Production and Utilisation of Hydrogen Peroxide Associated With Melanogenesis and Tyrosinase-Mediated Oxidations of DOPA and Dopamine", FEBS Journal, 272(10), 2005, pp. 2407-2415.

3. S.H.Hamed, P. Sriwiiyanont, R.R. Wickett and R.Boissy, "Effect of Deoxyarbutin on Melanogenesis: In vivo Comparison with Other Melanogenesis Inhibitor," Journal of Cosmatic Science, 55(1), 2004, pp.118-119.

4. P.O.Odumosu and TSO. Ekwe, "Identification and Spectrophotometric Determination of Hydroquinone Levels in Some Cosmatics Creams," African Journal of Pharmacy and Pharmacology, 4(5), 2010, pp.231-234.

5. P. Joseph, A.J.P.Klein-Szanto and A.K. Jaiswal, "Hydroquinones Cause Specific Mutations and Lead to Cellular Transformator and in vivo Tumorgenesis", Br. Journal Cancer, 78(3), 1998, pp. 312-320.

6. Environmental Assessment Office of Res. Dev. Cincinnati OH. U.S. Environmental Protection Agency (1993). "Integrated Risk Information System (IRIS) on Hydroquinone" Environmental Criteria and assessmnet office, Office of Health and Enviromental Assessmnet, Cincinnati, OH.

7. M.Borremans, J. Debber and L. Goeyens, "Experimental and Statistical Validation of HPLC Analysis of Hydroquinone and its 4-methoxy phenol, 4-ethoxy phenol and 4-benzyloxy phenol ethers in Cosmatics Products". Chromatographia, Wiesbaden, 50(516), 1999, pp. 346-352.

8. J. Firth and I. Rix, "Determination of Hydroquinone in Skin Toning Creams Using High Performance Liquid Chromatography". Analyst. Letch Worth, 111(2), 1986, pp. 129-132.

9. A. Amato Gagliardi, G. Cavazzutti, F. Chimenti, A. Bolasco and D. Tonelli, "Identification and Quantification of Hydroquinone and Some of its ethers in Cosmatics Products by Reversed Phase High Performance Liquid Chromatography". J. Chromatogr. Amsterdam, 404(1), 1978, pp. 267-272.

10. S. Saima, P. Zahida, A. Zeeshan and Z. Muhammad, "Qualitative and Quantitaive Estimation of Hydroquinone in Skin Whitening Cosmatics". J. Cosmacits, Dermatological Sci. and Appl. 2, 2012, pp. 224-228.

11. C. Desiderio, L.Ossicini and S. Fanali, "Analysis of Hydroquinone and Some of its Ethers by Using Capillary Electrochromatography”. J. Chromatogr. Amsterdam, 887(2), 2000, pp. 681-689.

12. V. I. Cruz and O. fatiblo. "Biosensor Based on Paraffin/graphite Modified with Sweet Potato Tissue for the Determination of Hydroquinone in Cosmatics Creamsin Orgaanic Phase". Talanta. Amsterdam, 52(4), 2000, pp. 681-689.

13. T. Hossein, A.K. Mohammed and F. Parisa, "Application of an Orthogonal Array Design for Optimization of Reaction Between $\mathrm{KMnO}_{4}$ and Hydroquinone in Alkaline Medium for Determination of Hydroquinone by kinetic Spectrophotometric Method". Asian J. Biochem. and Pharma Res. 1, 2011, pp. 264-272.

14. L.G. Perdo, I.R. Maria, K.S. Anil and R.M. Erika, "Determination of Wavelength and Derivative Order in Spectrophotomerty for Quantitation of Hydroquinone in Creams". Brazillian J. of Pharm. Sci. 43(3), 2007, pp. 397-404.

15. S. Uddin, A. Rauf, T.G. Kazi, H.I. Afridi and G. Lutfullah, "Highly Sensetive Spectrometric Method for Determination of Hydroquinone in Skin Lightening creams: application in Cosmatics". International J.of Cosmatics Sciences, 33, 2011, pp. 132.137.

16. L.Wang, "Simultaneous Determination of Hydrquinone Ethers in Cosmatics after Preconcentration at a Carbon Paste Electrode". Analyst Letch worth, 120(8), 1995, pp. 2241-2244. 